\title{
Investigation Of Natural Extracts As Green Corrosion Inhibitors In Steel Using Density Functional Theory
}

\author{
Muhamad Akrom \\ Department of Computer Science, Dian Nuswantoro University, Semarang, Indonesia, 50131 \\ Email : m.akrom@dsn.dinus.ac.id
}

Diterima (04 Januari 2022), Direvisi (29 Januari 2022)

\begin{abstract}
Steel is a material that has low resistance to corrosion when interacting with a corrosive environment. The application of natural extracts as green inhibitors is able to provide good performance in inhibiting corrosion of steel with high inhibition efficiency. Natural extracts that are effective and efficient as corrosion inhibitors on steel are those which in their compound structure contain heteroatom groups (such as $O, N, S, P$ ) and aromatic rings. This work provides an important comparative overview for the development of green inhibitor natural extracts in steel. The results of theoretical studies based on quantum mechanics with the DFT method at the atomic level based on molecular orbitals, chemical quantum parameters, and adsorption characteristics show results that are in accordance with experimental studies. The frontier molecular orbital (FMO) plot shows the distribution of electron density in the HOMO-LUMO region as a predictor of the active site of the inhibitor molecule interacting with the steel surface. Quantum chemical parameters such as ionization potential (I), electron affinity (A), absolute electronegativity ( () , hardness $(\eta)$, softness $(\sigma)$, fraction of electrons transferred $(\Delta N)$, electrophilicity $(\omega)$, and electron backdonation (UEback-donation) was calculated to obtain a correlation between the electronic properties of the inhibitor molecule and the corrosion inhibition potential. The results of the calculation of the quantum chemical parameters show the reactivity of the inhibitor molecule which has a very good potential to interact and bind strongly to the steel surface. This has the potential to make the inhibitor molecule have a high inhibition efficiency. Chemical adsorption and/or physical adsorption by forming complex compounds between inhibitor molecules and the steel surface are corrosion inhibition mechanisms to protect steel from a corrosive environment.The development of future studies should be able to display the mechanism of interaction and inhibition of inhibitor molecules in more detail and systematically at the atomic level on several metal surfaces such as $\mathrm{Fe}, \mathrm{Al}, \mathrm{Cu}$, and others.
\end{abstract}

Keywords: steel, natural product, green corrosion inhibitor, inhibition efficiency, DFT.

\begin{abstract}
Abstrak. Baja merupakan salah satu material yang memiliki ketahanan rendah terhadap korosi ketika berinteraksi dengan lingkungan korosif. Penerapan ekstrak bahan alam sebagai green inhibitor mampu memberikan performa yang baik dalam menghambat korosi pada baja dengan efisiensi inhibisi yang tinggi. Ekstrak bahan alam yang efektif dan efisien sebagai inhibitor korosi pada baja adalah yang dalam struktur senyawanya mengandung gugus heteroatom (seperti $\mathrm{O}, \mathrm{N}, \mathrm{S}, \mathrm{P}$ ) dan cincin aromatik. Karya ini memberikan tinjauan komparatif penting bagi pengembangan green inhibitor ekstrak bahan alam pada baja. Hasil kajian teoriti berbasis mekanika kuantum dengan metode DFT pada level atomik berdasarkan orbital molekuler, parameter kuantum kimia, dan karakterikstik adsorpsi menunjukkan hasil yang sesuai dengan kajian eksperimental. Plot $(F M O)$ menunjukkan distribusi kerapatan elektron pada daerah HOMO-LUMO sebagai prediksi situs aktif dari molekul inhibitor yang berinteraksi dengan permukaan baja. Parameter kimia kuantum seperti potensial ionisasi (I), afinitas elektron (A), elektronegativitas absolut ( $\chi$ ), hardness ( $\eta)$, softness $(\sigma)$, fraksi elektron yang ditransfer $(\Delta N)$, elektrofilisitas $(\omega)$, dan donasi-balik elektron $\left(\Delta E_{\text {back-donation }}\right)$ dihitung untuk mendapatkan korelasi antara sifat elektronik molekul inhibitor dengan potensi penghambatan (inhibisi) korosi. Hasil kalkulasi parameter kimia kuantum menunjukkan reaktivitas molekul inhibitor yang memiliki potensi yang sangat baik untuk dapat berinteraksi dan berikatan kuat dengan permukaan baja. Hal tersebut berpotensi menjadikan molekul inhibitor memiliki efisiensi inhibisi yang tinggi. Adsorpsi kimia dan/atau adsorpsi fisika dengan membentuk senyawa kompleks antara molekul inhibitor dengan permukaan baja merupakan mekanisme inhibisi korosi untuk melindungi baja dari lingkungan korosif. Pengembangan penelitian selanjutnya harus dapat menampilkan mekanisme interaksi dan inhibisi molekul inhibitor secara lebih rinci dan sistematis pada tingkat atomik pada beberapa permukaan logam seperti $\mathrm{Fe}, \mathrm{Al}, \mathrm{Cu}$, dan lainlain.
\end{abstract}


Kata kunci: baja, ekstrak bahan alam, green inhibitor korosi, efisiensi inhibisi, DFT.

\section{INTRODUCTION}

One of the materials that has attractive mechanical properties and high availability and can be fabricated easily and cheaply is steel. Therefore, steel is widely used for various uses, such as in industry and manufacturing [1][2]. However, the resistance of steel to corrosion when in a corrosive environment is weak [3][4]. Corrosion causes enormous losses in various sectors such as economic, environmental, social, industrial, security, safety, etc. [5][6][7]. Global costs for corrosion treatment reach $3.4 \%$ of global GDP or about US\$ 2.5 trillion per year [8][9]. The increase in these costs over the last decade has continued to increase [10]. Therefore, corrosion needs to be controlled.

The use of corrosion inhibitors is still one of the appropriate technologies to inhibit corrosion. Around 875 billion dollars per year or $35 \%$ of consumption costs can be saved by using corrosion inhibitors [11]. Inhibitors are chemical compounds which when added to a corrosive environment (electrolytes) in small amounts will be able to inhibit the corrosion process. The study of corrosion inhibitors is a very important study. It has been studied for many years the use of plant extracts as corrosion inhibitors based on natural materials, so that the development of technology for the application of corrosion inhibitors to inhibit material degradation continues to develop. The topic of studies regarding green corrosion inhibitors is currently very active.

Experimentally, the performance of corrosion inhibitors is generally evaluated by methods such as gravimetric analysis, potentiodynamic polarization, and electrochemical impedance spectroscopy. However, this experimental method is usually expensive, time-consuming and has not been able to clearly explain the interaction mechanism of inhibitor molecules with metal surfaces [5][12]. Recently, the density functional theory (DFT) based method is widely recognized as a reliable and inexpensive computational calculation method. In recent years, DFT is widely used in materials engineering research. DFT can be used to understand the interaction of molecules with metal surfaces, so that specific information is obtained at the atomic scale such as molecular structure, adsorption geometry, electronic properties, energy calculations, electron transfer to the material surface, and so on. This approach is able to provide relatively intuitive information about the interaction between the inhibitor and the metal surface and is effective in revealing the impact of small modifications in the inhibitor structure on its inhibitory efficiency and helps develop new inhibitors in an efficient and inexpensive way $[5][12][13][14]$.

\section{METHOD}

This work is an overview of the use of plant extract-based corrosion inhibitors on steel using the DFT method. This work can be an important comparative literature for the development and use of green inhibitors. This section describes the extracts of natural ingredients as green corrosion inhibitors and the methods used in this work.

\section{Extracts of Natural Products as Green Corrosion Inhibitors on Steel}

Nowadays, the development of corrosion inhibitors based on natural extracts (green inhibitors) continues to emerge because they are environmentally friendly, renewable, biodegradable, nonpollutant, non-toxic, easy to produce, 
inexpensive, and have high anti-corrosion efficiency [15][16]. An efficient green inhibitor is a compound which in its structure contains an aromatic ring and a heteroatom group (such as $\mathrm{O}, \mathrm{N}, \mathrm{S}, \mathrm{P}$ ). Several studies of corrosion inhibitors both experimentally and theoretically have been successfully carried out. Utilization of the compound 2-isopropyl-5-methylphenol derived from thyme extract showed that the experimental inhibition efficiency was $82.7 \%$ and $82.7 \%$ was obtained theoretically. The inhibition efficiency obtained experimentally and theoretically showed the same value, which was $90.8 \%$ in the study of thiamide-pyrazolindol derivatives [17].

Inhibition efficiency or inhibition efficiency (EI) is the level of decrease in corrosion activity due to the inhibitor's performance in protecting metal [18]. The inhibition efficiency can be determined based on the corrosion current using the potentiodynamic polarization method. The corrosion current is proportional to the corrosion rate. The corrosion rate indicates the efficiency of the inhibition. So, the lower the corrosion current, the lower the corrosion rate. The lower the corrosion rate, the higher the inhibition efficiency [19][20]. Following are the results of a recent study on the performance of several inhibitors of natural extracts on steel in $\mathrm{HCl}$ medium based on the inhibition efficiency obtained by the potentiodynamic polarization method as shown in Table 1. It can be seen in Table 1, that plant extracts have good performance based on the inhibition efficiency as shown in Table 1. corrosion inhibitor on steel in a hydrochloric acid environment.

Table 1. Inhibition Efficiency (IE) of green inhibition at inhibitor concentration of 1000 ppm and medium concentration of $1 \mathrm{M} \mathrm{HCl}$ on steel based on potentiodynamic polarization method.

\begin{tabular}{lll} 
Green Inhibitor & IE $(\%)$ & Ref. \\
& & \\
\hline Artichoke & 98.7 & {$[21]$} \\
Chamomile flower & 97 & {$[22]$} \\
Pineapple stem & 95.5 & {$[23]$} \\
Chaesalpinia pulch. & 95 & {$[24]$} \\
Thymus vulgaris & 95 & {$[25]$} \\
Primula vulgaris & 94.4 & {$[26]$} \\
Plantago & 92.5 & {$[27]$} \\
Juglans regia & 94.2 & {$[28]$} \\
Cassia occidentalis & 93 & {$[29]$} \\
Mangifera indica & 92.2 & {$[30]$} \\
\hline
\end{tabular}

\section{Density Functional Theory (DFT)}

Density functional theory (DFT) is the right method for predicting material structure, electronic properties, and interactions between materials. DFT is an approximation method (ab initio) in quantum mechanics calculations based on electron density. The electron density as a function of the total energy of the atomic nucleus and electron system. The electron density contains very important information about the characteristics of the material system in the ground state [5]. The results of the DFT calculations provide specific information on the atomic scale of the most stable configuration of structures with minimum values. The particle system will always lead to the most minimum energy through iterations of the scf (self consistent field) calculation that is carried out repeatedly until it gets a consistent amount of electron density which is the electron density in the ground state [5]. The calculation of the DFT method is not affected by the size of the system so that it is able to solve problems in many electron systems, such as complex molecular systems, where the calculations are able to represent experimental results.

In material systems, the study of quantum mechanics involves interactions between electrons and nuclei. The material 
system is described as a wave function $(\psi)$. A common approach to solving wave functions is the Schrödinger equation which is generally used in simple particle systems. In many-particle (N-particle) systems, a precise approximation is needed to solve the Schrödinger equation for manyparticles. One of the approximation methods for many-particle systems is DFT. The DFT method begins with the Hohenberg-Kohn model which states that the total electronic energy of the system is a function of electron density as equation (1).

$E(\rho)=T(\rho)+V_{\text {ee }}(\rho)+V_{\text {ext }}(\rho)$

where $T(\rho)$ is the kinetic energy of electrons originating from electron dynamics, $\operatorname{Vee}(\rho)$ is the potential energy of electron-electron interactions, $\mathrm{V}_{\text {ext }}(\rho)$ is the potential energy of electron-nuclear interactions. The index "ext" stands for "external" which indicates that the system focuses on electrons, so anything that is not derived from and related to electrons is considered external. The term $T(\rho)+\mathrm{V}_{\text {ee }}(\rho)$ is the Hartree-Fock energy or the Hohenberg-Kohn functional (FHK). However, the problem that has not been explained in the Hohenberg-Kohn model is that there is no explicit form of the functional kinetic energy of the electronelectron interaction in terms of electron density. The problem in the HohenbergKohn model is solved by the Kohn-Sham model by formally separating the Hohenberg-Kohn functional as equation (2).

$T(\rho)=T_{s}(\rho)+T_{c}(\rho)$

where the non-interacting kinetic energy $\operatorname{Ts}(\rho)$ is not equal to the interaction kinetic energy $T(\rho)$. The $T_{c}(\rho)$ part is the unknown part containing the difference between the functional $T(\rho)$ and the particle part $T_{s}(\rho)$ and the other part, which is considered as the remaining part of the total energy functional of the system. For the $V_{\text {ee }}(\rho)$ term in equation (3).

$\mathrm{V}_{\text {ee }}(\rho)=\mathrm{J}(\rho)+\mathrm{E}_{\text {nuc }}(\rho)$

where $J(\rho)$ is the result of the classical interaction which is part of the total potential energy of the electrons, and $E_{n u c}(\rho)$ is the interaction in the atomic nucleus which includes all the non-classical interactions. Equation (1) can now be written as equation (4).

$\mathrm{E}(\rho)=\mathrm{T}_{\mathrm{s}}(\rho)+\mathrm{J}(\rho)+\mathrm{V}_{\text {ext }}(\rho)+$

$E_{\text {nuc }}(\rho)+E_{x c}(\rho)$

where $T_{s}(\rho)$ is the kinetic energy of the electron, $J(\rho)$ is the Coulomb interaction potential between the electrons, $\mathrm{V}_{\text {ext }}(\rho)$ is the Coulomb interaction potential between the electrons and the nucleus, $E_{n u c}(\rho)$ is the Coulomb interaction potential between the nuclei, and $E_{x c}(\rho)$ is an exchangecorrelation function which is the other part that is not well known and shows the energy correction due to the two particles being exchanged, as well as the energy correction in the form of the energy difference between the interacting particle system and the system. particles that do not interact with each other [31].

\section{DISCUSSIONS}

The DFT method has been widely applied to investigate the electronic properties of inhibitor molecules related to the corrosion process, including molecular orbital energy (HOMO-LUMO energy), electrostatic potential maps, quantum chemical reactivity, and adsorption energy. 


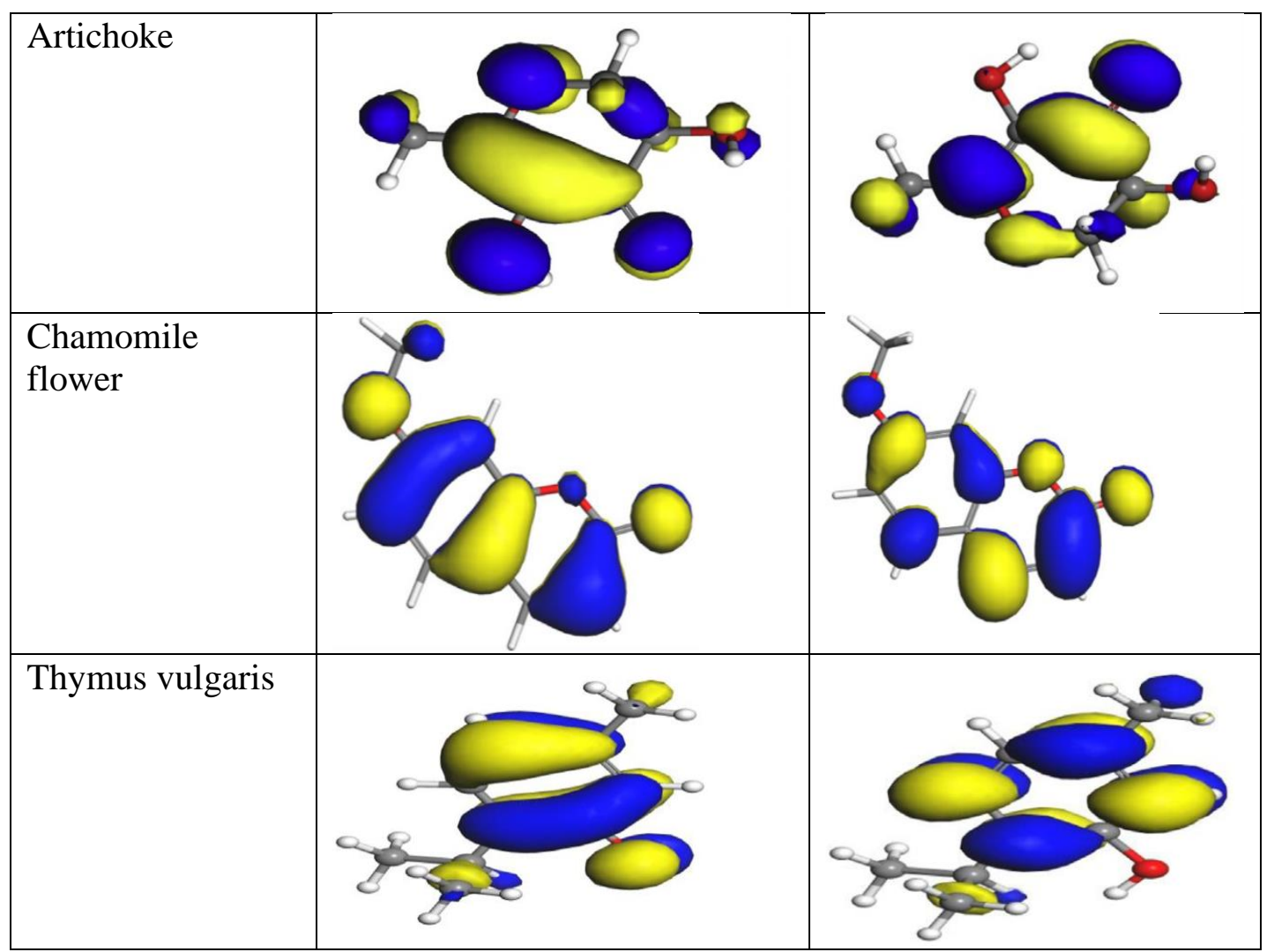

Figure 1. Distribution of HOMO-LUMO orbitals for green inhibitor extracts [21][22][25]

Molecular Orbitals and Energy HOMOLUMO

The distribution of electron density through the plot of frontier molecular orbitals (FMO) illustrates the prediction of active sites (adsorption centers) through the distribution of the HOMO-LUMO region of inhibitor molecules that interact with metal surfaces. HOMO (highest occupied molecular orbital) is the highest molecular orbital that contains electrons, while LUMO (lowest unoccupied molecular orbital) is the lowest orbital that does not contain electrons. HOMO describes the ability of inhibitor molecules as electron donors, while LUMO describes the properties of inhibitor molecules as electron acceptors. Figure 1 depicts the distribution of orbital electron density (HOMO and LUMO) of Artichoke, Chamomile flower, and Thymus vulgaris extract compounds. It can be seen that the distribution of electron density in the HOMO region tends to be localized around the two oxygen atoms and the aromatic ring, this is thought to be the region with the highest tendency to donate electrons, meaning that this part of the atoms is thought to be the center of the interaction. While the LUMO region is spread over the carbon chain and the benzene cycle, this is estimated to be the area with the highest tendency to accept electrons (acceptors). This implies that the molecular mechanism of these compounds is through the lone pair of electrons on the oxygen atom and/or the -electrons of the benzene ring. This explains that the potential interaction of inhibitor molecules with metal surfaces tends to be through a donor-acceptor mechanism. The distribution of orbital electron density (HOMO and LUMO) of Artichoke, Chamomile flower, and Thymus vulgaris extract compounds is shown in Figure 1. 
Electron transfer can be studied through HOMO-LUMO orbital conditions based on their energy values [32]. The inhibitor molecule is not only an electron donor to the metal surface, but also acts as an electron acceptor from the metal surface. A high Eномо value indicates that the inhibitor molecule's ability to donate electrons to a metal surface has a good potential, while a low $\mathrm{E}_{\mathrm{LUMO}}$ value indicates that the inhibitor molecule's ability to accept electrons from a metal surface has a good potential [14].

The energy gap $\left(\mathrm{E}_{\mathrm{gap}}\right)$ is the energy difference between LUMO and HOMO, which indicates the level of ability of the inhibitor molecule to bind to the metal surface. The energy gap can be calculated based on equation (5).

$\mathrm{E}_{\mathrm{gap}}=\mathrm{E}_{\mathrm{LUMO}}-\mathrm{E}_{\mathrm{HOMO}}$

The low energy gap value indicates that the molecule requires low energy to release electrons from the HOMO orbital to the LUMO orbital. The low energy gap indicates that the inhibitor molecule has a high level of reactivity, so the corrosion inhibition rate is good [33][34]. The electronic energy values of several natural extract compounds are shown in Table 2.

Table 2. Electronic energy of green inhibitor extract compounds

\begin{tabular}{llll}
\hline Green Inhibitor & Eномо & ELUMo & Egap \\
\hline Artichoke & -6.430 & -3.086 & 3.344 \\
Chamomile flower & -5.547 & -2.632 & 2.915 \\
Thynus vulgaris & -5.225 & -0.818 & 4.407 \\
\hline
\end{tabular}

In Table 2, it can be seen that Artichoke, Chamomile flower, and Thymus vulgaris extract compounds have high

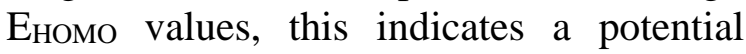
tendency to easily donate electrons when adsorbed on metal surfaces. On the other hand, a low $E_{\text {LUMO }}$ value indicates a potential tendency to accept electrons from metals. The low energy gap value indicates that the electrons in the inhibitor molecule tend to be easily excited from the HOMO orbital to the LUMO orbital.

To obtain the correlation between the electronic properties of the inhibitor molecule and the corrosion inhibition potential, quantum chemical calculations were carried out.

\section{Quantum Chemical Descriptors}

Quantum chemical parameters such as ionization potential (I), electron affinity (A), global hardness ( $\eta$ ), absolute electronegativity $(\chi)$, global softness $(\sigma)$, electron transfer fraction $(\Delta \mathrm{N})$, global electrophilicity $(\Phi)$ and back donation Electron electron affinity ( $\Delta$ Ebackdonation) is presented in Table 3. Ionization potential and electron affinity also explain the level of reactivity of the inhibitor molecule. A low ionization potential indicates that the inhibitor molecule has high reactivity, so the efficiency of inhibition is higher. In Koopman's theorem, the relationship between $\mathrm{E}_{\mathrm{HOMO}}$ and $\mathrm{E}_{\mathrm{LUMO}}$ is shown with the value of ionization potential (I) and electron affinity (A) as shown in equations (6) and (7) below.

$\mathrm{I}=-\mathrm{E}_{\mathrm{HOMO}}$

$A=-E_{\text {LUMO }}$

Electronegativity is related to the ability of the inhibitor molecule to attract electrons so that electron balance is achieved. The low electronegativity value indicates that the reactivity of the inhibitor molecule is high, so that the corrosion inhibition is higher (Kumar et al., 2020). The electronegativity value can be calculated by equation (8).

$\chi=\frac{\mathrm{I}+\mathrm{A}}{2}$ 
Hardness indicates the resistance of a molecule to transfer charge, while softness indicates the capacity of a molecule to accept charge. A low hardness value or a high softness value indicates that the molecule has high reactivity, meaning that it is easier to react and form bonds with metals, so that corrosion inhibition is higher [32]. Softness is the inverse of hardness. Hardness $(\eta)$ and softness $(\sigma)$ values can be calculated using the following equations (9) and (10).

$$
\begin{aligned}
\eta & =\frac{\mathrm{I}-\mathrm{A}}{2} \\
\sigma & =\frac{1}{\eta}
\end{aligned}
$$

The dipole moment $(\mu)$ describes the distribution of electrons in the molecular structure. The value of the dipole moment can be calculated using the equation below. The higher the value of the dipole moment, the higher the reactivity. This is related to the contact area between the inhibitor molecule and the metal surface which leads to a better corrosion inhibition ability [35][36]. The dipole moment can be calculated by equation (11).

$\mu=-\chi$

Electrophilicity $(\omega)$ also describes the ability of a molecule to absorb electrons. The lower the electrophilicity value, the molecule has high reactivity, meaning that it will be easier to bind to metal surfaces, so that corrosion inhibition increases [14][37]. Nucleophilicity $(\varepsilon)$ is the inverse of electrophilicity. The second equation can be written in equation (12) and (13).

$$
\begin{aligned}
& \omega=\frac{\mu^{2}}{2 \eta} \\
& \varepsilon=\frac{1}{\omega}
\end{aligned}
$$

Electron back-donation ( $\left.\Delta \mathrm{E}_{\text {back-donation }}\right)$ explains that the transfer of charge to the molecule is followed by the back-donation of the molecule. The more negative value of Eback-donation indicates better corrosion inhibition. The value of $\Delta \mathrm{E}_{\text {back- }}$ donation can be calculated from equation (14).

$\Delta \mathrm{E}_{\text {back-donation }}=-\frac{\eta}{4}$

When the inhibitor molecule and the metal surface interact, there will be a flow of electrons from the inhibitor molecule to the metal surface atom. The transfer of electrons occurs because of the difference in the value of the electronegativity between the inhibitor molecule and the metal surface. Electrons will move from the inhibitor molecule (low electronegativity) to the metal surface (high electronegativity) until the chemical potential is in equilibrium [38]. The value of $\Delta \mathrm{N}$ can be calculated using equation (15).

$\Delta \mathrm{N}=\frac{\chi \mathrm{met}-\chi \mathrm{inh}}{2(\eta \operatorname{met}+\eta \operatorname{inh})}$

where $\chi_{\text {met }}$ and $\chi_{\text {inh }}$ are the electronegativity values of the metal and inhibitor molecule, respectively, while $\eta_{\text {met }}$ and $\eta_{\text {inh }}$ are the hardness values of the metal and inhibitor molecule, respectively. Assuming that the theoretical value of $\chi_{\text {iron }}=7 \mathrm{eV}$ and $\eta_{\text {iron }}=0$ $\mathrm{eV}$ [39]. Actually, the use of the value of $\chi_{\text {iron }}=7 \mathrm{eV}$ is conceptually inaccurate, because it only relates to the Fermi energy of the free electron gas of iron, where electron-electron interactions are not considered. For this reason, the work function $(\phi)$ of the metal surface is used to replace met. So, the equation $\Delta \mathrm{N}$ becomes equation (16).

$\Delta \mathrm{N}=\frac{\phi \log -\chi \operatorname{inh}}{2(\eta \log +\eta \operatorname{inh})}$

Based on the DFT calculation, the value of obtained is $4.84 \mathrm{eV}$ for the surface of $\mathrm{Fe}$ (110) [40]. Electron transfer will occur from the inhibitor molecule to the 
metal surface if $\Delta \mathrm{N}>0$ and vice versa if $\Delta \mathrm{N}<0$. The electron donating ability of the inhibitor molecule increases if the value of $\Delta \mathrm{N}<3.6$ [14]. The quantum chemical parameters of some compounds are shown in Table 3.

Table 3. Quantum chemical parameters of green inhibitor compounds

\begin{tabular}{llllll}
\hline $\begin{array}{l}\text { Green } \\
\text { Inhibitor }\end{array}$ & $\mathbf{A}$ & $\mathbf{I}$ & $\mathbf{X}$ & $\boldsymbol{\eta}$ & $\mathbf{\Delta N}$ \\
\hline Artichoke & 3.0 & 6.4 & 4.7 & 1.6 & 0.01 \\
& 9 & 3 & 6 & 7 & 9 \\
Chamomil & 2.6 & 5.5 & 4.0 & 1.4 & 0.25 \\
e flower & 3 & 5 & 9 & 6 & \\
Thynus & 0.8 & 5.2 & 3.0 & 2.2 & 0.41 \\
vulgaris & 2 & 3 & 2 & 0 & \\
\hline
\end{tabular}

Based on Table 3, the extract compounds of Artichoke, Chamomile flower, and Thymus vulgaris have good chemical reactivity. It shows a very good potential to interact and bind strongly to metal surfaces, so it has the potential to be used as an effective corrosion inhibitor with high inhibition efficiency.

\section{Corrosion Inhibition Mechanism}

In general, the mechanism of corrosion inhibition (inhibition) can be through chemical adsorption and/or physical adsorption to form complex compounds between inhibitor molecules and the metal surface. The effectiveness of green corrosion inhibitors depends on their ability to form complex compounds as protective layers on metal surfaces so that they can prevent interactions with the corrosive environment that occur through charge and mass transfer [41][42]. An illustration of the adsorption mechanism of several inhibitor compounds can be seen in Figure 2 and Figure 3.

The adsorbed layer is formed by coordinating covalent bonds through the lone pair donor-acceptor phenomenon of the inhibitor molecule heteroatom group with the vacant d-orbital of the iron surface atom and/or the interaction between the electron of the inhibitory moleule aromatic ring and the vacant d-orbital of the iron surface atom. The active group or functional group (such as a heteroatom) on the inhibitor molecule will donate free electrons to the empty d-orbital of the metal surface, while the $\pi$-orbital on the aromatic ring of the inhibitor molecule will accept the $\pi$-electron from the empty d-orbital of the metal [17][43][44].

The adsorption energy indicates the stability of the molecule to form complex compounds with metal surfaces. The higher the adsorption energy, the more stable the complex formed. The adsorption energy can be calculated according to equation (17).

$E_{\text {ads }}=E_{\text {inh/surf }}-\left(E_{\text {inh }}+E_{\text {surf }}\right)$

where $E_{a d s}$ is the adsorption energy or the interaction energy. $E_{\text {inh/surf }}$ is the total energy between the metal surface and the adsorbed inhibitor molecule. Esurface is the total energy of the metal surface. The inhibitor is the total energy of the inhibitor molecule. In general, corrosion inhibition is achieved through the interaction between the inhibitor molecule and the metal surface. The ability of the inhibitor to be adsorbed on the metal surface is related to the efficiency of corrosion inhibition (Arrousse et al., 2021). The adsorbed layer can inhibit the transfer of charge between the electrolyte and the metal surface, thereby inhibiting the corrosion current. A low current density indicates a low corrosion rate. Low corrosion rate indicates high inhibition efficiency (Dehghani et al., 2020; Arrousse et al., 2021). The adsorption energy of several inhibitor compounds can be seen in Table 4.

Table 4. Energy of adsorption of Artichoke, Chamomile flower, and Thymus vulgaris extracts on iron surfaces 


\begin{tabular}{lc}
\hline Green Inhibitor & Eads $(\mathbf{k c a l} / \mathbf{m o l})$ \\
\hline Artichoke & -115.90 \\
Chamomile flower & -111.17 \\
Thynus vulgaris & -90.67 \\
\hline
\end{tabular}

Based on Table 4, the adsorption of Artichoke, Chamomile flower, and Thymus vulgaris extracts was energetically strong and was in accordance with the experimentally obtained inhibition efficiency.

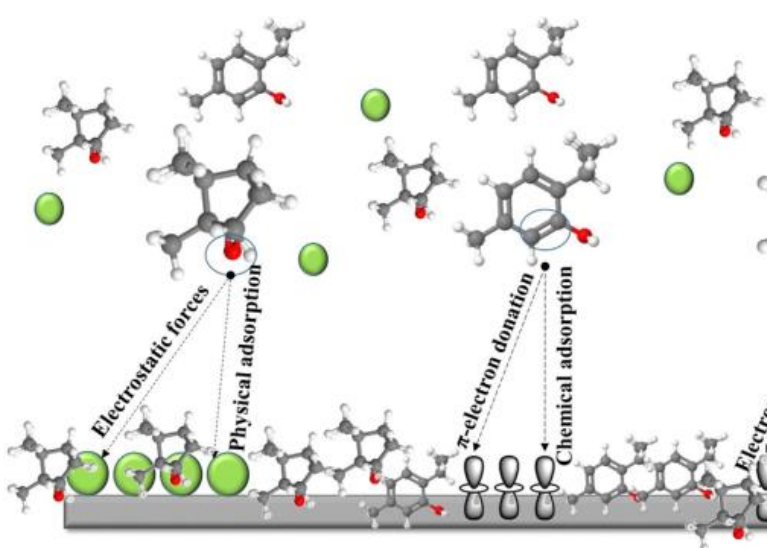

Figure 2. Schematic of the corrosion inhibition mechanism of Chamomile flower extract on the substrate [22]

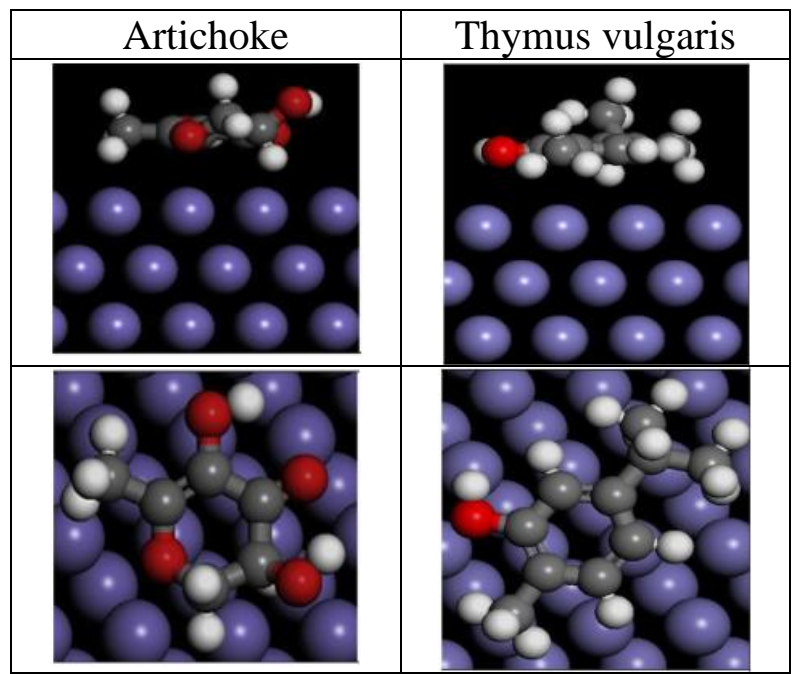

Figure 3. Adsorption of Artichoke and Thymus vulgaris extracts on Fe surface [21][25]

\section{CONCLUSION}

Investigations using the DFT method based on molecular orbital characteristics, quantum chemical calculations, and adsorption mechanisms showed that green inhibitor plant extracts have very good potential to be used as corrosion inhibitors. These results are in accordance with the inhibition efficiency obtained based on the experimental method. The development of further studies will investigate the mechanism of inhibition of inhibitor molecules in more detail and systematically at the atomic level on several metal surfaces such as $\mathrm{Fe}, \mathrm{Al}, \mathrm{Cu}$, and others.

\section{REFERENCES}

[1] D. I. Njoku, Y. Li, H. Lgaz, and E. E. Oguzie, "Dispersive adsorption of Xylopia aethiopica constituents on carbon steel in acid-chloride medium: A combined experimental and theoretical approach," J. Mol. Liq., vol. 249, pp. 371-388, 2018, doi: 10.1016/j.molliq.2017.11.051.

[2] R. Hsissou, S. About, R. Seghiri, M. Rehioui, A. Berisha, H. Erramli, A. Elharfi, M. Assouag, "Evaluation of corrosion inhibition performance of phosphorus polymer for carbon steel in $[1 \mathrm{M}] \mathrm{HCl}$ : Computational studies (DFT, MC and MD simulations)," $J$. Mater. Res. Technol., vol. 9, no. 3, pp. 2691-2703, 2020, doi: 10.1016/j.jmrt.2020.01.002.

[3] E. Gutiérrez, J. A. Rodríguez, J. Cruz-Borbolla, J. G. AlvaradoRodríguez, and P. Thangarasu, "Development of a predictive model for corrosion inhibition of carbon steel by imidazole and benzimidazole derivatives," Corros. Sci., vol. 108, pp. 23-35, 2016, doi: 10.1016/j.corsci.2016.02.036.

[4] I. Ichchou, L. Larabi, H. Rouabhi, Y. Harek, and A. Fellah, "Electrochemical evaluation and DFT calculations of aromatic 
sulfonohydrazides as corrosion inhibitors for XC38 carbon steel in acidic media," J. Mol. Struct., vol. 1198, no. 2019, 2019, doi: 10.1016/j.molstruc.2019.126898.

[5] D. K. Verma, "Density Functional Theory (DFT) as a Powerful Tool for Designing Corrosion Inhibitors in Aqueous Phase," Adv. Eng. Test., 2018 , doi: 10.5772/intechopen.78333.

[6] A. Sedik, D. Lerari, A. Salci, S. Athmani, K. Bachari, I. H. Gecibesler, R. Solmaz, "Dardagan Fruit extract as eco-friendly corrosion inhibitor for mild steel in 1 $\mathrm{M} \mathrm{HCl}$ : Electrochemical and surface morphological studies," J. Taiwan Inst. Chem. Eng., vol. 107, no. xxxx, pp. 189-200, 2020, doi: 10.1016/j.jtice.2019.12.006.

[7] X. Chen, Y. Chen, J. Cui, Y. Li, Y. Liang, and G. Cao, "Molecular dynamics simulation and DFT calculation of 'green' scale and corrosion inhibitor," Comput. Mater. Sci., vol. 188, no. August 2020, p. 110229, 2021, doi: 10.1016/j.commatsci.2020.110229.

[8] G. Koch, J. Varney, N. Thompson, O. Moghissi, M. Gould, and J. Payer, "International Measures of Prevention, Application, and Economics of Corrosion Technologies Study," NACE Int., no. March 1, 2016, p. 216, 2016, [Online]. Available: http://impact.nace.org/executivesummary.aspx.

[9] M. C. Groenenboom, R. M. Anderson, D. J. Horton, Y. Basdogan, D. F. Roeper, S. A. Policastro, J. A. Keith, "Doped Amorphous Ti Oxides to Deoptimize
Oxygen Reduction Reaction Catalysis," J. Phys. Chem. C, vol. 121, no. 31, pp. 16825-16830, 2017, doi: 10.1021/acs.jpcc.7b04210.

[10] H. DorMohammadi, Q. Pang, L. Árnadóttir, and O. Burkan Isgor, "Atomistic simulation of initial stages of iron corrosion in pure water using reactive molecular dynamics," Comput. Mater. Sci., vol. 145, pp. 126-133, 2018, doi: 10.1016/j.commatsci.2017.12.044.

[11] S. Marzorati, L. Verotta, and S. P. Trasatti, "Green corrosion inhibitors from natural sources and biomass wastes," Molecules, vol. 24, no. 1, 2019 , doi: 10.3390/molecules24010048.

[12] A. Singh, K. R. Ansari, M. A. Quraishi, and S. Kaya, "Theoretically and experimentally exploring the corrosion inhibition of N80 steel by pyrazol derivatives in simulated acidizing environment," $J$. Mol. Struct., vol. 1206, p. 127685 , 2020, doi: 10.1016/j.molstruc.2020.127685.

[13] J. Zhao, Z. Wang, P. Guo, and Q. Luo, "Molecular level investigation of methane and carbon dioxide adsorption on $\mathrm{SiO} 2$ surface," Comput. Mater. Sci., vol. 168, no. June, pp. 213-220, 2019, doi: 10.1016/j.commatsci.2019.05.044.

[14] G. Gece and S. Bilgiç, "A computational study of two hexitol borates as corrosion inhibitors for steel," Int. J. Corros. Scale Inhib., vol. 6, no. 4, pp. 476-484, 2017, doi: 10.17675/2305-6894-2017-6-4-7.

[15] L. T. Popoola, "Organic green corrosion inhibitors (OGCIs): A 
critical review," Corros. Rev., vol. 37, no. 2, pp. 71-102, 2019, doi: 10.1515/corrrev-2018-0058.

[16] V. Vorobyova and M. Skiba, "Apricot pomace extract as a natural corrosion inhibitor of mild steel corrosion in $0.5 \mathrm{M} \mathrm{NaCl}$ solution: A combined experimental and theoretical approach," J. Chem. Technol. Metall., vol. 55, no. 1, pp. 210-222, 2020.

[17] S. Hadisaputra, A. A. Purwoko, A. Hakim, L. R. T. Savalas, R. Rahmawati, S. Hamdiani, N. Nuryono, "Ab initioMP2 and DFT studies of ethyl-p-methoxycinnamate and its derivatives as corrosion inhibitors of iron in acidic medium," J. Phys. Conf. Ser., vol. 1402, no. 5, 2019, doi: 10.1088/17426596/1402/5/055046.

[18] M. Pramudita, S. Sukirno, and M. Nasikin, "Rice Husk Extracts Ability to Reduce the Corrosion Rate of Mild Steel," Int. J. Chem. Eng. Appl., vol. 9, no. 4, pp. 143-146, 2018, doi: 10.18178/ijcea.2018.9.4.715.

[19] A. Dehghani, A. H. Mostafatabar, G. Bahlakeh, and B. Ramezanzadeh, "A detailed study on the synergistic corrosion inhibition impact of the Quercetin molecules and trivalent europium salt on mild steel; electrochemical/surface studies, DFT modeling, and MC/MD computer simulation," J. Mol. Liq., vol. 316, p. 113914, 2020, doi: 10.1016/j.molliq.2020.113914.

[20] N. Arrousse, R. Salim, Y. Kaddouri, A. Zarrouk, D. Zahri, F. E. Hajjaji, R. Touzani, M. Tleb, S. Jodeh, "The inhibition behavior of two pyrimidine-pyrazole derivatives against corrosion in hydrochloric solution: Experimental, surface analysis and in silico approach studies," Arab. J. Chem., vol. 13, no. 7, pp. 5949-5965, 2020, doi: 10.1016/j.arabjc.2020.04.030.

[21] A. Salmasifar, M. Edraki, E. Alibakhshi, B. Ramezanzadeh, and G. Bahlakeh, "Combined electrochemical/surface

investigations and computer modeling of the aquatic Artichoke extract molecules corrosion inhibition properties on the mild steel surface immersed in the acidic medium," J. Mol. Liq., vol. 327, p. 114856, 2021, doi: 10.1016/j.molliq.2020.114856.

[22] M. H. Shahini, M. Keramatinia, M. Ramezanzadeh, B. Ramezanzadeh, and G. Bahlakeh, "Combined atomic-scale/DFT-theoretical

simulations \& electrochemical assessments of the chamomile flower extract as a green corrosion inhibitor for mild steel in $\mathrm{HCl}$ solution," $J$. Mol. Liq., vol. 342, p. 117570, 2021, doi: 10.1016/j.molliq.2021.117570.

[23] M. Mobin, M. Basik, and J. Aslam, "Pineapple stem extract (Bromelain) as an environmental friendly novel corrosion inhibitor for low carbon steel in $1 \mathrm{M} \mathrm{HCl}$," Meas. J. Int. Meas. Confed., vol. 134, pp. 595605, 2019, doi: 10.1016/j.measurement.2018.11.003.

[24] K. Kanagavalli, "Caesalpinia pulcherrima as corrosion inhibitor for mild steel in Acid medium," vol. 5, no. 10, pp. 1411-1416, 2014.

[25] S. M. Lashgari, G. Bahlakeh, and B. Ramezanzadeh, "Detailed theoretical DFT computation/molecular 
simulation and electrochemical explorations of Thymus vulgaris leave extract for effective mild-steel corrosion retardation in $\mathrm{HCl}$ solution," J. Mol. Liq., vol. 335, p. 115897, 2021, doi: 10.1016/j.molliq.2021.115897.

[26] M. T. Majd, S. Asaldoust, G. Bahlakeh, B. Ramezanzadeh, and M. Ramezanzadeh, "Green method of carbon steel effective corrosion mitigation in $1 \mathrm{M} \mathrm{HCl}$ medium protected by Primula vulgaris flower aqueous extract via experimental, atomic-level MC/MD simulation and electronic-level DFT theoretical elucidation," J. Mol. Liq., vol. 284, pp. 658-674, 2019, doi: 10.1016/j.molliq.2019.04.037.

[27] M. Mobin and M. Rizvi, "Polysaccharide from Plantago as a green corrosion inhibitor for carbon steel in $1 \mathrm{M} \mathrm{HCl}$ solution," Carbohydr. Polym., vol. 160, pp. 172-183, 2017, doi: 10.1016/j.carbpol.2016.12.056.

[28] A. E. A. S. Fouda, S. M. Rashwan, M. M. Kamel, and E. A. Haleem, "Juglans regia extract (JRE) as ecofriendly inhibitor for aluminum metal in hydrochloric acid medium," Biointerface Res. Appl. Chem., vol. 10, no. 5, pp. 6398-6416, 2020, doi: 10.33263/BRIAC105.63986416.

[29] C. O. Akalezi, C. K. Enenebaku, and E. E. Oguzie, "Application of aqueous extracts of coffee senna for control of mild steel corrosion in acidic environments," Int. J. Ind. Chem., vol. 3, no. 1, pp. 1-12, 2012, doi: 10.1186/2228-5547-3-13.

[30] K. Karattu Veedu, T. Peringattu Kalarikkal, N. Jayakumar, and N. K.
Gopalan,

"Anticorrosive Performance of Mangifera indica L. Leaf Extract-Based Hybrid Coating on Steel," ACS Omega, vol. 4, no. 6, pp. 10176-10184, 2019, doi: 10.1021/acsomega.9b00632.

[31] C. F. Zinola, "Quantum and theoretical electrocatalysis," Electrocatal. Comput. Exp. Ind. Asp., pp. 77-98, 2010, doi: $10.1201 / 9781420045451$.

[32] L. G. Marni, E. Emriadi, S. Syukri, and I. Imelda, "Mempelajari inhibisi korosi senyawa khellin dan visnagin pada atom besi menggunakan metode DFT (density functional theory)," J. Litbang Ind., vol. 9, no. 2 , p. 111, 2019, doi: 10.24960/jli.v9i2.5403.111-118.

[33] B. TÜZÜN, "Investigation of Benzimidazole Derivates as Corrosion Inhibitor by DFT," Cumhur. Sci. J., vol. 40, no. 2, pp. 396-405, 2019, doi: 10.17776/csj.412611.

[34] N. Ammouchi, H. Allal, Y. Belhocine, S. Bettaz, and E. Zouaoui, "DFT computations and molecular dynamics investigations on conformers of some pyrazinamide derivatives as corrosion inhibitors for aluminum," J. Mol. Liq., vol. 300, p. 112309, 2020, doi: 10.1016/j.molliq.2019.112309.

[35] K. K. Anupama and A. Joseph, "Experimental and Theoretical Studies on Cinnamomum verum Leaf Extract and One of Its Major Components, Eugenol as Environmentally Benign Corrosion Inhibitors for Mild Steel in Acid Media," J. Bio- Tribo-Corrosion, vol. 4, no. 2, p. 0, 2018, doi: 


\subsection{7/s40735-018-0146-Z.}

[36]

D. Daouda, T. Douadi, D. Ghobrini, N. Lahouel, and H. Hamani, "Investigation of some phenolic-type antioxidants compounds extracted from biodiesel as green natural corrosion inhibitors; DFT and molecular dynamic simulation, comparative study," AIP Conf. Proc., vol. 2190, 2019, doi: $10.1063 / 1.5138584$.

[37] R. Farahati, H. Behzadi, S. M. Mousavi-Khoshdel, and A. Ghaffarinejad, "Evaluation of corrosion inhibition of 4-(pyridin-3yl) thiazol-2-amine for copper in $\mathrm{HCl}$ by experimental and theoretical studies," J. Mol. Struct., vol. 1205, p. 127658, 2020, doi: 10.1016/j.molstruc.2019.127658.

[38] A. A. El Hassani, Z. E. Adnani, A. T. Benjelloun, M. Sfaira, M. Benzakour, M. Mcharfi, B. Hammouti, K. M. Emran, "DFT Theoretical Study of 5-(4-R-Phenyl)1H-tetrazole $(\mathrm{R}=\mathrm{H}$; $\mathrm{OCH} 3 ; \mathrm{CH} 3$; $\mathrm{Cl})$ as Corrosion Inhibitors for Mild Steel in Hydrochloric Acid," Met. Mater. Int., vol. 26, no. 11, pp. 1725-1733, 2020, doi: 10.1007/s 12540-019-00381-5.

[39] V. S. Sastri and J. R. Perumareddi, "Molecular Orbital Theoretical Studies of Some Organic Corrosion Inhibitors," Corros., vol. 53, no. 8, pp. 617-622, 1997, doi: 10.5006/1.3290294.

[40] J. Radilla, G. E. Negrón-Silva, M. Palomar-Pardavé, M. Romero-Romo, and M. Galván, "DFT study of the adsorption of the corrosion inhibitor 2-mercaptoimidazole onto $\mathrm{Fe}\left(\begin{array}{lll}1 & 0 & 0\end{array}\right)$ surface," Electrochim. Acta, vol.
112, pp. 577-586, 2013, doi: 10.1016/j.electacta.2013.08.151.

[41] F. Nurul Affifah, E. Ginting, and S. Suprihatin, "Pengaruh Penambahan Inhibitor Ekstrak Daun Talas Dan Suhu Perendaman 40 Oc Dan 70 Oc Terhadap Laju Korosi Pada Baja Api 5L Dalam Larutan Nacl 3\%," Anal. Anal. Environ. Chem., vol. 4, no. 02, pp. $\quad 76-85, \quad 2019, \quad$ doi: 10.23960/aec.v4.i2.2019.p76-85.

[42] C. B. P. Kumar, M. K. Prashant, K. N. Mohana, M. B. Jagadheesha, M. S. Raghu, M. K. Lokanath, Mahesha, K. Y. Kumar, "Protection of mild steel corrosion by three new quinazoline derivatives: experimental and DFT studies," Surfaces and Interfaces, vol. 18, no. January, p. 100446, 2020, doi: 10.1016/j.surfin.2020.100446.

[43] S. Elmi, M. M. Foroughi, M. Dehdab, and M. Shahidi Zandi, "Computational evaluation of corrosion inhibition of four quinoline derivatives on carbon steel in aqueous phase," Iran. J. Chem. Chem. Eng., vol. 38, no. 1, pp. 185200, 2019.

[44] Y. Stiadi, S. Arief, H. Aziz, M. Efdi, and E. Emriadi, "INHIBISI KOROSI BAJA RINGAN MENGGUNAKAN BAHAN ALAMI DALAM MEDIUM ASAM KLORIDA: Review," J. Ris. Kim., vol. 10, no. 1, p. 51, 2019, doi: 10.25077/jrk.v12i2.321. 
Muhammad Akrom : Investigation Of Natural Extracts As Green Corrosion Inhibitors In Steel Using Density Functional Theor 